\title{
Performance and Energy Efficiency of New Rice Varieties Under Aerobic Growing Conditions, Different Tillage and Direct Seeding Methods in Kalinga, Philippines
}

\author{
Rafael J. Padre ${ }^{1, *}$, Ferdinand Ganotice ${ }^{1}$, Herbert Imatong ${ }^{1}$, \\ Kristine S. Pascual ${ }^{2}$ and Manuel Jose C.J. Regalado ${ }^{2}$ \\ ${ }^{1}$ College of Engineering and Information Technology, Kalinga State University, 3800 \\ City of Tabuk, Kalinga, Philippines \\ 2Engineering Mechanization Division, Philippine Rice Research Institute, Maligaya, \\ Science City of Munoz, Nueva Ecija, Philippines
}

\begin{abstract}
Article Type: Article
Article Citation: Rafael J. Padre, Ferdinand Ganotice, Herbert Imatong, Kristine S. Pascual, Manuel Jose C.J. Regalado. Performance and energy efficiency of new rice varieties under aerobic growing conditions, different tillage and direct seeding methods in Kalinga, Philippines. Indian Journal of Science and Technology. 2020; 13(05),493-501.D0l:10.17485/ijst/2020/ v013i05/144621
\end{abstract}

Received date: May 15, 2019

Accepted date: 0 ctober 18, 2019

*Author for correspondence: Rafael J.Padre \rjpadre2007@ yahoo.com 9 Kalinga State University, 3800 City of Tabuk, Kalinga, Philippines

\section{Abstract}

Objectives: To evaluate the performance of three (3) selected hybrid rice varieties, namely NSIC RC9 (V1), M19 (V2), M20 (V3) and one (1) inbred rice variety (M228) through minimum and conventional tillage with the use of different direct-seeding methods for seeding in aerobic condition in Kalinga, Philippines. Methods/analysis: The field experiment was laid out in a split-split-plot in RCBD with tillage, seeding method, and variety as treatments in four replications. The agronomic performance, yield performance, and energy efficiency of the rice varieties were evaluated in two cropping year from August 2013 to March 2015. Agronomic performance, such as seed emergence, height at maturity, number of productive tillers, length of panicles, percent of filled grains, weight of 1000 seeds, final grain yield of the said varieties were analyzed for each treatments. The cost effectiveness, labor productivity, and energy efficiency were also analyzed for each treatment. Findings: Generally, there are no significant differences of the selected varieties including the inbred variety in terms of seed emergence, plant height, length of panicle, productive tillers, and percent filled grains, 1000 grain weight and grain yield under tillage practices and different seeding techniques. In like manner, the agronomic and yield performance varied across varieties. Regardless of tillage practices, the varieties did not exhibit any significant differences in terms of production cost, labor productivity and energy efficiency after two cropping year. Furthermore, plastic drum seeding techniques found to be more cost effective, while Korean seeding technique had the highest labor productivity and most energy efficient. Based on the result of the study, the agronomic and yield performance of newly released varieties are comparable as to inbred varieties used while the used of plastic drum seeder had the lowest cost of production and 
highest overall energy ratio (OER). On the other hand, the highest labor productivity was observed from the used of Korean seeder. Novelty/improvement: This study demonstrated that selected rice varieties exhibited the same agronomic performance and yield performance under conservation and minimum tillage with different seeding techniques in Kalinga, Philippines. In addition, the production cost, labor productivity, and energy efficiency depend from seeding techniques to be employed.

Keywords: Energy Efficiency, Aerobic, Tillage, Direct Seeding, Labor Productivity.

\section{Introduction}

Cultivation of newly release input-responsive rice varieties in a well-drained, nonpuddled, and non-saturated soils ("aerobic soil"), without ponded water, is one of the production systems that is less popular to farmers owing to low yield. This technology was first introduced in the Philippines by the International Rice Research Institute in the early 2001. Aerobic rice requires supplemental irrigation and external inputs (fertilizers) to achieve its potential yields. It has an intermediate feature which combines the drought tolerance of upland rice varieties with the high - yielding characteristics of lowland rice varieties.

However, growing aerobic rice varieties in aerobic condition cannot stand alone to increase agricultural productivity unless power, fertilizer and rainfall or supplemental irrigation are available at the right time and applied efficiently.

This study aims to evaluate the performance of newly released hybrid and inbred rice varieties under different tillage and direct-seeding methods and aerobic condition in Kalinga; Specifically, aims to determine the agronomic and yield performance of new hybrid and inbred varieties under aerobic conditions, minimum tillage and mechanized direct seeding method; and determine the advantages of minimum tillage and alternative seeding methods, in terms of energy efficiency, labor productivity, and cost effectiveness.

\section{Conceptual Framework}

The performance of three (3) selected hybrid rice varieties, namely NSIC RC9 (V1), M19 (V2), M20 (V3) and one (1) inbred rice variety (M228) through minimum and conventional tillage with the use of different direct-seeding methods for seeding in aerobic condition in Kalinga, Philippines was evaluated in two cropping seasons started from August 2014 to March 2015. Agronomic performance, such as seed emergence, height at maturity, number of productive tillers, length of panicles, percent of filled grains, weight of 1000 seeds, final grain yield of the said varieties were analyzed for each treatment. Performance as to the cost effectiveness, labor productivity and energy efficiency of the varieties in a minimum and conventional tillage methods of dibbling, plastic drum seeder and Korean seeder for 
seeding were evaluated. The data were analyzed using the Randomized Complete Block Design (RCBD) two factorial with tillage methods as factor A and seeding methods as factor B.

\section{Methodology}

\subsection{Experimental Site and Design}

The field experiment was conducted in two cropping years at a rainfed area in Tabuk City, Kalinga from August 2014 to March 2015. It was laid out in a split-split-plot in RCBD with tillage $\times$ seeding method $\times$ variety as treatments in four replications. The main plot (10 $\times 45 \mathrm{~m}$ ) consisted of conventional tillage (T1) and minimum tillage (T2); Sub-plots (10 $\times 15 \mathrm{~m}$ ) consisted of seeding methods such as Korean seeder (S1), Plastic drum seeder (S2) and Dibbling (S3); and the sub-sub plots $(2.5 \times 15 \mathrm{~m})$ consisted of varieties such as NSIC Rc 9 (V1), M19 (V2), M20 (V3) with two different varieties of V4 which is M228 in the first cropping year (2014) while NSIC 298 for the second cropping year (2015). Treatments under conventional tillage were plowed once and harrowed twice, at one week interval using hand tractor with disk plow for plowing and hand tractor with harrow for harrowing. The first harrowing was done after plowing to break the clods and incorporate the stubbles. The second harrowing was done across the direction of the first plow to further incorporate the volunteer plants and other organic materials. For minimum tillage, it was plowed once and harrowed once only. The final leveling was done on both conventional and minimum tillage one day before seeding. Seeds were sown at a seeding rate of $40 \mathrm{~kg} /$ ha. Post emergence herbicides were applied at 6 and 30 days after seeding. Figures 1 shows the experimental set-up during the first cropping year (2014) in Kalinga.

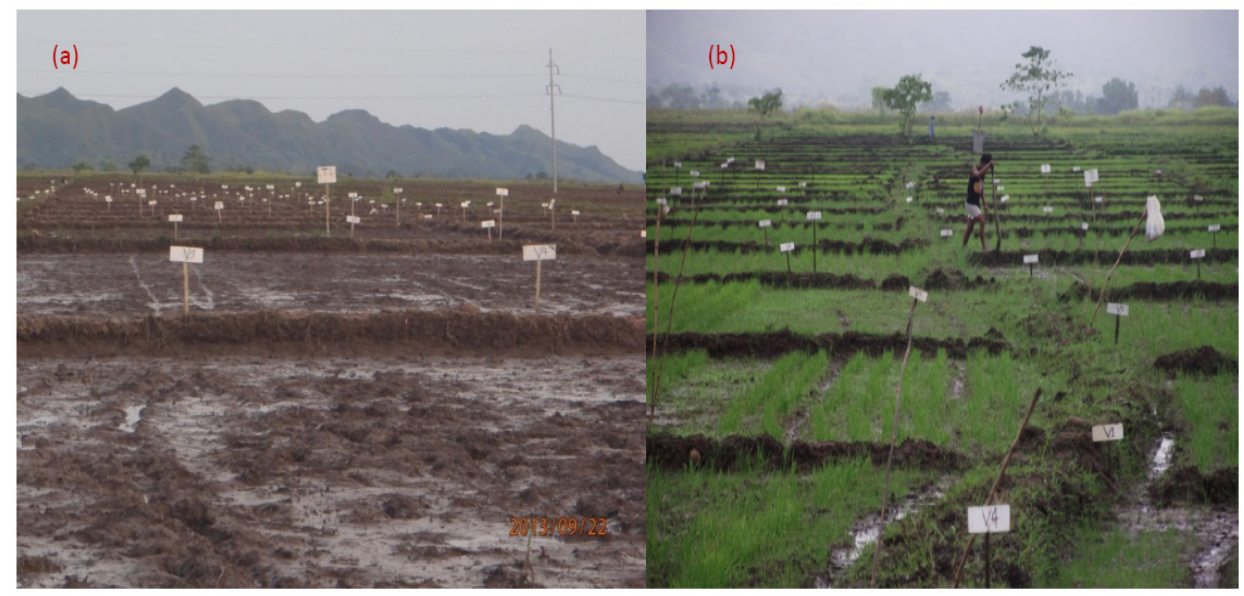

FIGURE 1. Field plots showing the experimental set-up (a) before sowing and at (b) 7 days after sowing. 


\subsection{Agronomic Performance}

Agronomic characteristics such as seed emergence, plant height, number of productive tillers, length of panicle, percent filled grains, weight of 1000 seeds, and grain yields were measured using the following methods.

The seed emergence of the different rice varieties under tillage practices and seeding methods were obtained from a linear meter portion in each plot with 100 seeds at 14 DAS.

For the plant height, it was measured from the base of the plant to the tip of the tallest panicle at maturity. Ten hills taken from a $1 \mathrm{~m}$ length from each plot were measured.

On the number of productive tillers, productive tillers were obtained from tillers with well-developed panicles and grains. These were counted from $1 \mathrm{~m}$ length of row at harvest time.

The panicle length was measured from the base of the panicle (neck node) to its tip while the percent filled grains were computed from the total number of filled grains divided by the total number of filled and unfilled grains.

The weight of 1000 seeds was taken from the composite seed samples from the pool of harvest from each treatment was weighed after drying to $14 \%$ moisture content using a $0.01 \mathrm{~g}$ sensitivity digital weighing balance. Grain yield for each treatment was computed based on the yield of sampling area of $5 \mathrm{~m}^{2}$.

\subsection{Unit production Cost and Labor Productivity}

The unit production cost, was obtained by determining the ratio of the sum of all costs of production input (seeds, fertilizers, pesticides, labor, fuel, machine hiring, and irrigation fees) per hectare to the total grain yield per hectare, expressed in Philippine peso per kilogram of paddy (Php/kg). No supplemental irrigations were employed throughout the cropping season.

Labor productivity is the efficiency in the direct use of field manpower in rice production and is expressed in terms of unit weight of paddy output per man-day. This was measured as the ratio of the total yield of paddy in $\mathrm{kg} / \mathrm{hectare}$ to the total number of man-days devoted for one hectare in the entire growing season, from seedling and land preparation to hauling of the harvested crop.

\subsection{Energy Efficiency}

The overall energy ratio (OER) was determined as the ratio of the total output energy (OET) to the total input energy (IET). The OET in MJ/ha was obtained following the recommended method [1]. On the other hand, IET was determined by summing up all energy inputs such as direct energy use per hectare for each field operation [2], energy associated with fuel use [1,3], indirect energy contribution of machinery for each field operation [4], indirect energy of other inputs, such as fertilizers, pesticide and seed [5] and the energy input corresponding to human labor at every stage of production process [3]. 


\section{Results and Discussion}

\subsection{Agronomic Performance}

\subsubsection{Seed Emergence}

Seed emergence between tillage did not show any significant differences, but among varieties and seeders are highly significant.

The percentage seed emergence across varieties ranged from 79.58 to $86.38 \%$ in 2014 while a uniform of $90 \%$ in 2015 (Table 1). The relatively low percentage seed emergence obtained on the first cropping year experiment could be attributed to the unfavorable weather condition during sowing up to 7 DAS in the area.

\subsubsection{The Plant Height}

The plant height among tillage and seeding methods did not show any significant differences. However, varieties varied significantly at $p=0.01$. The variety NSIC RC9 (V1) achieved the tallest followed by, M20 (V3), M19 (V2), and V4 (M228) in both cropping years (Table 1). The variation in height is in agreement to Phil Rice report (dbmp.philrice.gov.ph). This variation in plant height is probably caused by differences in varietal characteristics.

\subsubsection{Number of Productive Tillers}

Results showed that productive tillers among tillage and seeding methods did not show any significant differences, but only among varieties which are highly significant. Productive tillers of V1 obtained the lowest among treatments in 2014 and 2015. Results also showed that panicle length among tillage and seeding methods did not show any significant differences, but only among varieties which are highly significant. Panicle length of V1 obtained the longest $(23.69 \mathrm{~cm})$, followed by V3 (21.95), V2 (20.98), and V4 (20.28) during the first cropping year (2014). This panicle length and variety trends in the first cropping season is consistent with the result in the second cropping season. The weight of the 1000 filled grain varied significantly among varieties. The V3 and V1 achieved the heaviest and lowest weight in the first and second cropping year (Table 1). These results of the study agree with the results of rainfed lowland rice improvements [6].

\subsubsection{Grain Yields}

Grain yields were significantly influenced by varieties. The average grain yield of the different rice variety ranges from $3100.88 \mathrm{~kg} / \mathrm{ha}$ to 4135.67 for the first cropping year and from $4002.77 \mathrm{~kg} / \mathrm{ha}$ to $4053.18 \mathrm{~kg} / \mathrm{ha}$ for the second cropping year. Variety V3 and V2 obtained the highest grain yield during the first cropping year while V1 and V2 gained the highest grain yield during the second cropping year (Table 1). The average grain yield of the different varieties used in the study is in agreement with the research findings on the yield of aerobic rice in rainfed lowlands of the Philippines as affected by nitrogen management and row spacing whose yields were ranging from 3.1 to 4.9 tons/ha [7]. 


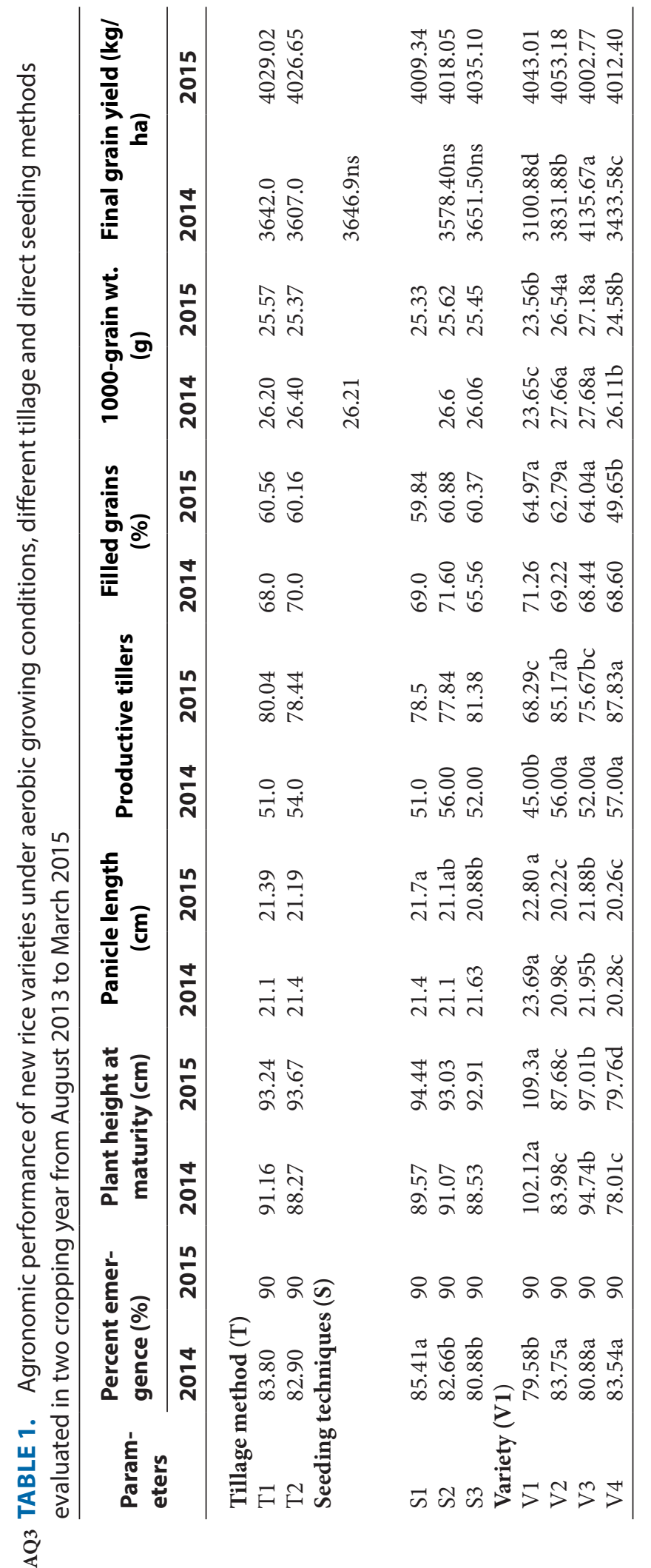


TABLE 1A. Summary of the analysis of variance

\begin{tabular}{lllllllllllllll}
\hline Block & $\star *$ & $\mathrm{~ns}$ & $\star \star$ & $\mathrm{ns}$ & $\mathrm{ns}$ & $\mathrm{ns}$ & $\mathrm{ns}$ & $\mathrm{ns}$ & $\mathrm{ns}$ & $\mathrm{ns}$ & $\mathrm{ns}$ & $\mathrm{ns}$ & $\mathrm{ns}$ & $\mathrm{ns}$ \\
Tillage (A) & $\mathrm{ns}$ & $\mathrm{ns}$ & $\mathrm{ns}$ & $\mathrm{ns}$ & $\mathrm{ns}$ & $\mathrm{ns}$ & $\mathrm{ns}$ & $\mathrm{ns}$ & $\mathrm{ns}$ & $\mathrm{ns}$ & $\mathrm{ns}$ & $\mathrm{ns}$ & $\mathrm{ns}$ & $\mathrm{ns}$ \\
Seeding(B) & $\star *$ & $\mathrm{~ns}$ & $\mathrm{~ns}$ & $\mathrm{~ns}$ & $\mathrm{~ns}$ & $\star$ & $\mathrm{ns}$ & $\mathrm{ns}$ & $\mathrm{ns}$ & $\mathrm{ns}$ & $\mathrm{ns}$ & $\mathrm{ns}$ & $\mathrm{ns}$ & $\mathrm{ns}$ \\
A x B & $\mathrm{ns}$ & $\mathrm{ns}$ & $\mathrm{ns}$ & $\mathrm{ns}$ & $\mathrm{ns}$ & $\mathrm{ns}$ & $\mathrm{ns}$ & $\mathrm{ns}$ & $\mathrm{ns}$ & $\mathrm{ns}$ & $\mathrm{ns}$ & $\mathrm{ns}$ & $\mathrm{ns}$ & $\mathrm{ns}$ \\
Variety (C) & $\star \star$ & $\mathrm{ns}$ & $\star \star$ & $\star$ & $\star \star$ & $\star$ & $\mathrm{ns}$ & $\star$ & $\star \star$ & $\star$ & $\star \star$ & $\star$ & $\star \star$ & $\mathrm{ns}$ \\
A x C & $\mathrm{ns}$ & $\mathrm{ns}$ & $\mathrm{ns}$ & $\mathrm{ns}$ & $\mathrm{ns}$ & $\mathrm{ns}$ & $\mathrm{ns}$ & $\mathrm{ns}$ & $\mathrm{ns}$ & $\mathrm{ns}$ & $\mathrm{ns}$ & $\mathrm{ns}$ & $\mathrm{ns}$ & $\mathrm{ns}$ \\
B x C & $\mathrm{ns}$ & $\mathrm{ns}$ & $\mathrm{ns}$ & $\mathrm{ns}$ & $\mathrm{ns}$ & $\mathrm{ns}$ & $\mathrm{ns}$ & $\mathrm{ns}$ & $\mathrm{ns}$ & $\mathrm{ns}$ & $\mathrm{ns}$ & $\mathrm{ns}$ & $\mathrm{ns}$ & $\mathrm{ns}$ \\
A x B x C & $\mathrm{ns}$ & $\mathrm{ns}$ & $\mathrm{ns}$ & $\mathrm{ns}$ & $\mathrm{ns}$ & $\mathrm{ns}$ & $\mathrm{ns}$ & $\mathrm{ns}$ & $\mathrm{ns}$ & $\mathrm{ns}$ & $\mathrm{ns}$ & $\mathrm{ns}$ & $\mathrm{ns}$ & $\star$ \\
\hline
\end{tabular}

${ }^{*}$ Significant at $5 \%$ level.

${ }^{* *}$ Highly significant at $1 \%$ level.

In a column, means followed by the same letter are not significantly different at 0.05 level of probability by Least Significant Difference (LSD). T1 - Minimum tillage; T2 - Conventional tillage; S1 - Korean seeder; S2 - Plastic drum seeder; S3 -

Dibbling; V1 - NSIC Rc9, V2 - M19, V3 - M20, V4 - M228.

\subsection{Production Cost and Labor Productivity}

The production cost was significantly influenced by variety and its interacting effects with seeding method. Among varieties, V1 and V3 obtained the highest and lowest cost with Php 10.66/kg and Php 8.69/kg, respectively in 2014 while V3 and V2 had the highest and lowest production cost in the second cropping year with Php 8.84/kg and Php 8.76/kg. Variations on the production cost among varieties were attributed on grain yields and the number of manual labor incurred particularly in the filling-up of vacant hills during the first cropping year. It was also observed that under rainy weather conditions, S1 has the ability to cover seeds during seeding which protects seeds from run-off. Hence, less incidence of missing hills. The production cost across varieties in this study is generally better than the average production of cost per kilogram in the country which is Php 12.41/ $\mathrm{kg}[8]$.

Results also showed that labor productivity was influenced by varieties and its interacting effects with seeding methods. The V3 and V1 achieved highly significant values of labor productivity with 98.58 and $73.33 \mathrm{~kg} / \mathrm{man}$-days, respectively in 2014 (Table 2). Variations on the labor productivity among varieties were attributed on grain yields and the number of manual labor incurred particularly in the filling-up of vacant hills. Korean seeder has the ability to cover seeds upon seeding which protects seeds from rain. Hence, labor productivity under S1 is better than the other seeding methods, particularly during rainy season because of less incidence of missing hills. In 2015, the highest and lowest labor productivity was obtained under V2 and V3, respectively. The labor productivity in the Philippines from 1985 to 1990 is $21 \mathrm{~kg} /$ day [9].

This study showed that the labor productivity regardless of variety is almost 4-5 times greater than the previous decades. The positive result is attributed to improved variety used.

\subsection{Energy Efficiency}

In general, the study shows that regardless of tillage practice, variety and seeding technique, it is an energy efficient $(\mathrm{OER}>1)$. This study demonstrated that the introduced production system under rainfed areas in the province of Kalinga is gaining energy [2]. 
Performance and Energy Efficiency of New Rice Varieties Under Aerobic Growing Conditions, Different Tillage and Direct Seeding Methods in Kalinga, Philippines

TABLE 2. Unit production cost, labor productivity and energy efficiency of new rice varieties under aerobic growing conditions, different tillage and direct seeding methods evaluated in two cropping year from August 2013 to March 2015

\begin{tabular}{lcccccc}
\hline Parameters & \multicolumn{2}{c}{$\begin{array}{c}\text { Unit production } \\
\text { cost (Php/kg) }\end{array}$} & \multicolumn{2}{c}{$\begin{array}{c}\text { Labor productivity } \\
\text { (kg/man-days) }\end{array}$} & \multicolumn{2}{c}{$\begin{array}{c}\text { Overall energy } \\
\text { ratio (\%) } \\
\text { energy efficient) }\end{array}$} \\
\cline { 2 - 8 } & $\mathbf{2 0 1 4}$ & $\mathbf{2 0 1 5}$ & $\mathbf{2 0 1 4}$ & $\mathbf{2 0 1 5}$ & $\mathbf{2 0 1 4}$ & $\mathbf{2 0 1 5}$ \\
\hline Tillage method & & & & & & \\
T1 & 9.70 & 8.798 & 91.16 & 78.97 & $6.9 \mathrm{~ns}$ & 7.54 \\
T2 & 9.50 & 8.801 & $85.10 \mathrm{~ns}$ & 81.34 & $6.8 \mathrm{~ns}$ & 7.55 \\
Seeding techniques $\mathbf{( S )}$ & & & & & \\
S1 & 9.60 & $8.85 \mathrm{~b}$ & $99.09 \mathrm{a}$ & 89.63 & $7.04 \mathrm{~ns}$ & $7.59 \mathrm{~b}$ \\
S2 & 9.58 & $8.61 \mathrm{a}$ & $82.81 \mathrm{a}$ & 89.22 & $6.72 \mathrm{~ns}$ & $7.65 \mathrm{a}$ \\
S3 & 9.65 & $8.95 \mathrm{~b}$ & $76.59 \mathrm{a}$ & 61.62 & $6.86 \mathrm{~ns}$ & $7.38 \mathrm{~b}$ \\
Variety (V1) & & & & & & \\
V1 & $10.66 \mathrm{a}$ & 8.78 & $73.33 \mathrm{a}$ & 80.44 & $5.88 \mathrm{a}$ & 7.57 \\
V2 & $9.24 \mathrm{c}$ & 8.76 & $91.75 \mathrm{c}$ & 81.04 & $7.21 \mathrm{c}$ & 7.59 \\
V3 & $8.69 \mathrm{~d}$ & 8.84 & $98.58 \mathrm{~b}$ & 79.31 & $7.93 \mathrm{~b}$ & 7.50 \\
V4 & $9.87 \mathrm{~b}$ & 8.83 & $81.00 \mathrm{c}$ & 79.84 & $6.50 \mathrm{c}$ & 7.52 \\
\hline
\end{tabular}

TABLE 2A. Summary of the analysis of variance

\begin{tabular}{lllllll}
\hline Block & $\mathrm{ns}$ & $\mathrm{ns}$ & $\star *$ & $\mathrm{~ns}$ & $\mathrm{~ns}$ & $\mathrm{~ns}$ \\
Tillage (A) & $\mathrm{ns}$ & $\mathrm{ns}$ & $\mathrm{ns}$ & $\mathrm{ns}$ & $\mathrm{ns}$ & $\mathrm{ns}$ \\
Seeding (B) & $\mathrm{ns}$ & $\star$ & $\star *$ & $\star$ & $\mathrm{ns}$ & $\star$ \\
A x B & $\mathrm{ns}$ & $\mathrm{ns}$ & $\mathrm{ns}$ & $\star$ & $\mathrm{ns}$ & $\mathrm{ns}$ \\
Variety (C) & $* *$ & $\mathrm{~ns}$ & $\star *$ & $\mathrm{~ns}$ & $\star \star$ & $\mathrm{ns}$ \\
A x C & $\mathrm{ns}$ & $\mathrm{ns}$ & $\mathrm{ns}$ & $\mathrm{ns}$ & $\mathrm{ns}$ & $\mathrm{ns}$ \\
B x C & $\star$ & $\mathrm{ns}$ & $\star *$ & $\mathrm{~ns}$ & $\star$ & $\mathrm{ns}$ \\
A x B x C & $\mathrm{ns}$ & $\star$ & $\mathrm{ns}$ & $\star$ & $\mathrm{ns}$ & $\star$ \\
\hline
\end{tabular}

* Significant at $5 \%$ level.

** Highly significant at $1 \%$ level.

In a column, means followed by the same letter are not significantly different at 0.05 level of probability by Least Significant Difference (LSD).

T1 - Minimum Tillage; T2 - Conventional tillage; S1 - Korean seeder; S2 - Plastic drum seeder; S3 - Dibbling; V1 - NSIC Rc9, V2 - M19, V3 - M20, V4 -M228.

\section{Conclusion}

- There is no variation on the seed emergence, plant height, length of panicle, productive tillers, and \% filled grains, 1000 grain weight and grain yield under minimum and conventional tillage.

- Seed emergence, plant height, length of panicle, productive tillers, and \% filled grains varied across varieties. In 2014, the seed emergence across varieties was ranged from $79.58 \%$ to 86.38 . Plant was tallest at V1 $(102.12 \mathrm{~cm})$; the lowest number of productive tillers was recorded at V4 (45). V1 produced the highest percentage of filled grains (71). Weight of 1000 seeds was heaviest at V3 with 27.68g. The highest grain yield among treatments was V3 with $4135.67 \mathrm{~kg}$. In the second cropping year (2015), the 
agronomic and yield performance of the newly released varieties including the inbred variety used generally did not exhibit any significant differences.

- Among the varietal treatments, V3 and V2 has the lowest unit production cost in the first cropping season and second cropping year respectively, In addition, V3 in the first cropping year and V2 in the second cropping year are highest in terms of labor productivity and overall energy ratio.

- There is an interaction effects among seeding methods and variety in terms of unit production cost, labor productivity and over all energy ratio in the first cropping year while interaction effects among tillage practice, seeding and variety was obtained in terms of production cost, labor productivity and OER in the second cropping year.

- Plastic drum seeder had the lowest unit production cost and highest in OER while Korean seeder exhibited the highest labor productivity.

- Furthermore, the result of this study can already serve as basis for establishing rice production in a well-drained, non-puddled, and non-saturated soils ("aerobic soil"), in the province of Kalinga, Philippines.

\section{References}

1. A method for determining the total energy input for agricultural practices. http://agris.fao.org/ agris-search/search.do? recordID=US19800581769. Date accessed: 1979.

2. Bockari-Gevao SM, Wanshick WI, Azmi Y, Cham CW. Analysis of energy consumption in lowland rice based cropping system of Malaysia. Songklanakarin Journal of Science and Technology. 2005; 27(4), 820-827.

3. Energy consumption in wheat production in irrigated and dry land farming. https://www. researchgate.net/publication/281324606_Fuel_consumption_in_wheat_production_in_ irrigated_and_dry_land_farming. Date accessed: 01/2002.

4. Energy inputs in production agriculture. http://agris.fao.org/agris-search/search. do? recordID=US201301760969. Date accessed: 1992.

5. A energy use in agriculture: an overview. http://citeseerx.ist.psu.edu/viewdoc/download?doi=10 .1.1.543.5844\&rep=rep1\&type $=$ pdf. Date accessed: 1999 .

6. Rainfed lowland rice improvement. http://books.irri.org/971220071X_content.pdf. Date accessed: 1996.

7. Lampayan RM, Bouman B, de Dios JL, Espiritu AJ. Yield of aerobic rice in rainfed lowlands of the Philippines as affected by nitrogen management and row spacing. Field Crops Research. 2010; 116(1-2), 165-174.

8. Competitiveness of Philippine rice in Asia. https://www.cardph.com/single-post/2017/05/30/ Competitiveness-of-Philippine-Rice-in-ASIA. Date accessed: 2016.

9. Pierre Van de Eng PV. Productivity and comparative advantage in rice agriculture in South East Asia since 1870. Asian Economic Journal. 2014; 18(4), 345-370. 